\section{A VOCAÇÃo UNIVERSAL DO DIREITO INTERNACIONAL PRIVADO -} TENDÊNCIAS ATUAIS

\section{Erik Jayme}

Vice-Presidente do Curatorium de l'Académie de Droit International de Lo Haye (Tradução Nádia de Araúio, PUC-RJ)

Discurso por ocasião da inauguração do novo prédio da Academia da Haia, 18 de Janeiro de 2007.

Majestade, Excelentíssimos, caros Colegas, Senhoras e Senhores.

A Academia, desde sempre, tem enfatizado a unidade do Direito Internacional público e privado, seja no ensino, seja no que se relaciona às pesquisas. A inauguração do novo prédio da Academia é o momento de lembrar a vocação universal do direito internacional privado e de meditar sobre as tendências atuais em matéria de conflitos de leis.

No começo do mês de dezembro do ano passado aconteceu em Porto Alegre, no Brasil, a conferência dos especialistas encarregados de preparar a CIDIP VII, a sétima Conferência Interamericana de direito internacional privado. O objeto desta conferência será a proteção do consumidor em Direito Internacional Privado, inclusive as questões de competência judiciária e do reconhecimento e da execução das decisões. É um fato notável, pois esta conferência uniu os páses de common law, como os Estados Unidos da América, e os páses de tradição de direito romano-germânico na América Latina. Além disso, são os mercados como o Mercosul que precisam de um direito internacional privado que corresponda às exigências do comércio. Em certos páses da América Latina, o direito internacional privado torna-se também o motor da reforma dos direitos nacionais em matéria de proteção do consumidor. Levam-se em conta os desenvolvimentos europeus, mas as soluções não são as mesmas. ${ }^{1}$ Enquanto o direito europeu está abandonando a idéia da autonomia da vontade das partes, os projetos americanos favorecem uma combinação entre o princípio da lei mais favorável ao consumidor e uma autonomia limitada, solução que entendo menos radical e mais equilibrada que o projeto comunitátio de um regulamento "Rome I".

Em Haia, é preciso invocar a grande tradição da Conferência de Haia de direito internacional privado.

O sucesso mundial das recentes convenções elaboradas no sentido da Conferência, como a relativa ao seqüestro de crianças e à adoção, deve-se sobretudo às novas técnicas conflituais, principalmente a criação de agências centrais que ajudam os mais fracos a fazer valerem seus direitos em situações transfronteiriças. A Conferência de Haia mantém de um modo admirável a idéia da vocação universal do direito internacional privado contra um certo eurocentrismo que apareceu recentemente nos esforços da Comunidade Européia, no sentido de unificar as regras sobre os conflitos de leis e os conflitos de jurisdição levando em conta sobretudo as necessidades de um mercado interno e deixando de lado os interesses das pessoas que vivem nos terceiros países. Por outro lado, nota-se com satisfação a cooperação entre as duas instituições que aparecem no regulamento "Bruxelles II bis" sobre as questões de autoridade parental, que contém regras especiais sobre seqüestro de menores, inspiradas na Convenção de Haia , regras suplementares que deixam o espaço da Convenção de Haia para atingir seus objetivos globais. ${ }^{2}$

Se falamos da vocação universal do direito internacional privado, nosso olhar se dirige às novas sociedades que se estão formando e entrando em cena no direito internacional privado. Por exemplo: na China existe uma sociedade científica de direito internacional privado. Em 2000 , este grupo de especialistas elaborou uma lei modelar de direito internacional privado com base na ciência jurídica contemporânea. Esta codificação figura atualmente no projeto de Código civil da República Popular da China que está sendo discutido pelo comitê permanente do congresso nacional. Devemos também falar da Índia e dos sistemas jurídicos da África ou da técnica conflitual da "opç̃o de estatuto" que permite manter a paz entre as diversas culturas.

Em relação ao ensino do direito internacional privado deve-se acentuar o direito comparado. Evidentemente, cada docente ministra seus cursos considerando seu próprio sistema de direito. Mas é a comparacão entre as soluções dadas pelas regras de conflitos de países de tradição diferente às questões de direito civil que permitem melhor compreender os problemas. Qualquer qualificação e qualquer interpretação de regras de conflitos pressupõe estudos de direito comparado. É nesta ótica que a Academia vai perseguir seus objetivos.

Em resumo, a vocação universal do direito internacional privado permanece como base dos trabalhos de nossa Academia, cujo novo edifício temos o grande prazer de inaugurar.

\section{Bibliografia:}

Pontes de Miranda, La conception du droit international privé d'après la doctrine et la pratique au Brésil, Recueil des Cours 39 ( 1932 - I), 555 - 675

Lima Marques, Claudia, A proposta brasileira de Convenção Interamericana de Direito Internacional Privado sobre a lei aplicável a alguns contratos com consumidores (CIDIP VID): temas e discussões no Forum de expertos da OEA, in: Universidade Federal do Rio Grande do Sul, Cadernos do Programa de pós-graduação em direito - PPGDir./UFRGS V (Março 2006), p. $75 \mathrm{~s}$.

Jayme, Erik, Völkerrecht und Intemationales Privatrecht - eine entwicklungsgeschichtliche Betrachtung in Stefan Leible e Matthias Ruffert (eds.), Völkerrecht und IPR, Jena 2006, p. 23 s.

Reimann, Mathias, Comparative Law and Private International Law, in: Mathias Reimann and Reinlard Zimmermann, The Oxford Handbook of Comparative Law, Chapter 42, p. 1363 s. (2006)

2 As convençōes de Haia constituem também um estreito liame entre o direito internacional privado e o diréto internaciona público. A ponte entre as duas matérias direito internacional permanecem os direitos do homem que inspitam a solucão dos casos concretos que inspiram um número crescente de decisões da Corte de Strasburgo enn matéria de litígios de diteito civil transfrontteiriço 